\title{
PROFITABILITY OF MV BORO RICE PRODUCTION UNDER SHALLOW TUBEWELL IRRIGATION SYSTEM IN SOME SELECTED AREAS OF TANGAIL DISTRICT
}

\author{
F. Nargis ${ }^{1}$, T. H. Miah ${ }^{2}$, T. S. Khanam ${ }^{3}$ and R. H. Sarwer ${ }^{4}$ \\ Department of Agricultural Economics, Bangladesh Agricultural University \\ Mymensingh-2202, Bangladesh
}

\begin{abstract}
The present study estimates profitability of MV Boro rice production under shallow tubewell irrigation system. The study was conducted in Ghatail upazila of Tangail district. In the study, 60 water buyers from 5 villages were randomly selected. The survey covered a whole period of MV Boro production (January to May 2008). The major findings of the study were that about one third of total cost shared by irrigation charge. Though, the water buyers made a significant profit from MV Boro paddy production but the buyers were not fully satisfied with the prevailing one-fourth water charge and claimed for reduction of water charge. Education and farming experience was the important tools to increase profit in MV Boro paddy production. A considerable further scope apparently exists for expansion of STWs by reducing water charge to enhance the productivity of MV Boro paddy and to increase farm income of water buyers.
\end{abstract}

Key words : Boro paddy production, Profit, Shallow tubewell Irrigation, Water buyers

\section{INTRODUCTION}

Bangladesh is a land of mighty rivers and innumerable tributaries, heavy rainfall and recurring floods. Yet, irrigation plays a vital role in this country for half of the year (mainly in dry season) when water scarcity seriously handicaps farming operation. In Bangladesh, optimum use of irrigation water should play an important role in increasing agricultural production. Overall development of the country's agricultural sector will require year-round use of irrigation facilities. Nearly 75 per cent of the country's population depends either directly or indirectly on agriculture. So, this sector's performance strongly affects Bangladesh's malnutrition and poverty levels. Rice is the major crop (grown on 80 per cent of the country's irrigated area). The yearly production

1 PhD Fellow, Sunchon National University, South Korea

2 Professor, Department of Agricultural Economics, Bangladesh Agricultural University, Mymensingh-2202, Bangladesh

${ }^{3}$ Research Assistant, FAO Funded Project "Livelihood Adaptation of Disadvantaged People of Bangladesh to Economic Volatity and other Shocks", BAU, Mymensingh, Bangladesh

${ }^{4}$ Data Analyst, World Fish Center, Khulna, Bangladesh 
of rice increased from around 10 million tonnes in the early 1970s to nearly 27 million tonnes in 2006 improving food self-sufficiency and food security nationally (BBS, 2006). Such growth has helped to reduce the percentage of poor in the country, from 58.8 per cent in 1992 to 49.8 per cent in 2000 (BBS 2006). The rice crop alone occupies 90 - 95 per cent of the irrigated area and only $5-10$ per cent is left for other crops. Cultivation of modern variety (MV) of rice during the Boro season is almost entirely dependent on irrigation water. Two types of irrigation equipment such as deep tubewell (DTW) and shallow tubewell (STW) were mainly used for groundwater irrigation. About 60 per cent areas are covered by STW (BBS 2006). Coverage of STWs irrigation areas has increased by about 17 per cent during the last 6 years (2000/01 - 2005/06) (BBS 2006). The STWs are operated by diesel and electricity. Electricity operated STWs have been increasing due to upward trend of diesel price. Mainly Crop share and cash payment systems have widely been used to irrigate rice field in Bangladesh. The demand for irrigation water has been increasing day by day and the cost is also increasing accordingly. By minimizing losses of irrigation water, more area can be irrigated with the same volume of water. If proper water management is practiced agricultural production can be increased through either higher yield or larger irrigated areas. Therefore, the importance of proper water management has widely been accepted by those concerned with irrigation and crop production. Under the situations, the study was design to identify socioeconomic status of water buyers and to estimate profitability of irrigated MV Boro paddy cultivation under diesel and electrically operated STWs.

\section{MATERIALS AND METHODS}

\section{The data and field survey}

Keeping in view the objectives of the study, the study area was chosen from an intensively irrigated area of Bangladesh. Data were collected from sixty randomly selected water buyers (30 under diesel operated shallow tubewells and 30 under electrically operated shallow tubewells) of five adjacent villages namely: Sheikh Shimul, Saitapara, Kurmushi, Kaijalipur and Kagmari Beltail of Dighalkandi union under Ghatail Upazila in Tangail district during the Boro season (January to April) of 2008.

\section{Analytical technique}

Production period of Boro rice was about four months and due to such short production period the following profit equation was fitted.

$\pi=P_{y} \cdot Y+P_{b} \cdot B-\sum_{i=1}^{n}(P x i . X i)-T F C$

Where,

$\pi=$ Net return or profit of MV Boro paddy (Tk/ha);

$\mathrm{Y}=$ Total quantities of paddy $(\mathrm{kg} / \mathrm{ha})$;

$\mathrm{P}_{\mathrm{y}}=$ Paddy price $(\mathrm{Tk} / \mathrm{kg})$;

$\mathrm{B}=$ Total quantities of straw $(\mathrm{Kg} / \mathrm{ha})$;

$\mathrm{P}_{\mathrm{b}}=$ Price of by-product; 
$X_{i}=$ Quantity of inputs (human labor, power tiller, seedling, fertilizer, insecticide etc., used for producing MV Boro paddy (Kg/ha);

$P_{x \mathrm{i}}=$ Input prices;

TFC $=$ total fixed cost involved in producing MV Boro paddy; and

$\mathrm{i}=1,2,3 \ldots, \mathrm{n}$ (number of inputs).

Rate of agriculture (production) loan was 10 per cent in 2007. Thus, 10 per cent discount rate has been chosen for the financial analysis of irrigation business.

\section{RESULTS AND DISCUSSION}

\section{Socioeconomic characteristics of water buyers}

About 37 per cent of the water buyers were aged between 40 to 50 years, they were middle aged and highest proportion than other age groups of farmers. Average family size of water buyers was 4.9, of which 2.66 numbers were males. Most of the male family members directly contributed in irrigating rice crop field. Farm size plays an important role in resource allocation in agricultural production (Yang, 1962). It appears from Table 1 that the average farm size was 0.91 ha for water buyers.

Table 1. Major socioeconomic characteristic of farmers

\begin{tabular}{l|c}
\hline \multicolumn{1}{c|}{ Socioeconomic indicators } & Water buyers \\
\hline Average age group (years) (40.01-50.00) & 36.67 \\
Year of schooling by heads & 2.2 \\
Family size (no.) & 4.9 \\
Farm size (ha) & 0.91 \\
\hline
\end{tabular}

Source : Nargis (2008)

Agriculture was the main source of income and occupation of livelihood of most of the people in the study areas. Almost all homestead areas were used for agriculture directly or indirectly. The agricultural practices were relatively intensive in this area due to the expansion of the irrigation facilities, use of modern varieties of Boro seed increasingly and expansion of power tiller uses. Generally two or three crops were grown from a plot of land in one year. Proportion of single cropped area was very low. Most of the areas under double cropped area and the rest were under triple cropped area. Most of the land was under irrigated condition except fallow land and water logging areas. Even from the low lying lands the farmers harvested two crops in a year. But the medium and moderate high land under irrigation facilities were used intensively for producing rice and non-rice crops. The cropping patterns of the study areas are mainly rice based. Transplanted Aman and MV Boro were the main rice crops. The winter crops like wheat, potato, mustard, pulses and vegetables like brinjal, tomato, bean, cucumber, lalshak etc., were also grown in the study areas. 


\section{Profitability of MV Boro paddy}

Human labour cost was one of the most important and largest cost items in the production process of MV Boro paddy. It required for different farm operations like land preparation, transplanting, weeding, application of fertilizers and insecticides, supplying irrigation water, harvesting and carrying, cleaning, drying, storing, etc. This was computed by converting all women and children hours into man equivalent hours by assigning a ratio of 2 children $=1.5$ women $=1$ male (Rahman, 2000; Ali, 2001).

Both human and hired labours were used to cultivate Boro paddy in the study areas. To produce one hectare of Boro paddy, 40 man-days hired labours and 21 man-days family labours were utilized. The average wage rate was Tk. 140 per man-day, although it varied during different intercultural operation in the same irrigation season (Table 2). Farmers generally paid higher wages during transplanting and harvesting period. The marginal farmers, who produced Boro paddy in rented in land they mainly used family labour to cultivate their plots. But the rich farmers highly depended on hired labour.

Table 2. Per hectare cost of MV Boro paddy production under STW irrigation

\begin{tabular}{l|c|c|c|c}
\hline \multicolumn{1}{c}{ Cost Items } & Quantity & Unit Price (Tk) & Total cost (Tk) & Per cent of total cost \\
\hline Human labour & 100 man-days & 140 & 14,000 & 37.11 \\
Power tiller & - & - & 2,470 & 6.55 \\
Seedlings & $56 \mathrm{Kg}$ & 53 & 2,968 & 7.87 \\
Urea & $292 \mathrm{Kg}$ & 6 & 1,752 & 4.64 \\
TSP & $120 \mathrm{Kg}$ & 16 & 1,600 & 4.24 \\
MP & $57 \mathrm{Kg}$ & 16 & 912 & 2.42 \\
Zinc and gypsum & $17 \mathrm{Kg}$ & 8 & 136 & 0.36 \\
Water charge & - & - & 12,750 & 33.81 \\
Insecticide and herbicide & - & - & 208 & 0.55 \\
Total variable cost & - & - & 36,796 & 97.56 \\
Interest on OC & - & - & 920 & 2.44 \\
Gross cost & - & - & 37,716 & 100.00 \\
\hline
\end{tabular}

Source : Nargis (2008)

The use of power tiller for land preparation has currently been increasing rapidly in the study villages. Most of the farmers used hired power tiller. There was a competitive ploughing rate of power tiller in the study areas as a good number of PTs were rented to plough the crop fields. Average per hectare tillage cost was Tk. 2,470 for two cross ploughings by power tiller (PT) at Tk. 5 per decimal per ploughing in Boro season.

Farmers used both home supplied and purchased seedlings. The average price of MV Boro seedling was Tk. 53.00 per kg. It was found that per hectare cost of MV Boro paddy seedlings was Tk. 2,968 which constituted 7.87 per cent of total costs (Table 2). Most of the farmers mainly used three types of fertilizer namely Urea, Tripple Super Phosphate (TSP) and Muriate of Potash (MP). The prices of fertilizers were Tk. 6.00 per kg for Urea, 
Tk. 16.00 per kg for TSP and MP, respectively. The farmers used $292 \mathrm{~kg}, 120 \mathrm{~kg}$ and $57 \mathrm{~kg}$ of Urea, TSP and MP, respectively, which represent 4.64, 4.24 and 2.42 per cent of total costs. Farmers had to use lower doses of fertilizer in the plots which were used for mustard cultivation just before Boro. Normally there has been a residual effect of fertilizer on the Boro rice as the farmers usually apply higher doses of fertilizer in mustard cultivation. The farmers generally did not apply any manure in their plots. Some farmers, however, used ash to increase soil fertility. Though, no established ash market was reported in the study area, the ash price was calculated at the rate of Tk. 0.5 per $\mathrm{kg}$ as some rice mill sold ash at this rate.

Irrigation was a leading input for MV Boro production. The cost of irrigation water was charged at fixed rate per unit of area. In the study area, farmers paid their irrigation charge in two installments. One installment was paid before harvesting and another installment was paid after harvesting. In the case of STWs operation, farmers paid $10 \mathrm{~kg}$ rice for lineman. Thus the per hectare water charge for irrigation water was Tk. 12,750 for MV Boro cultivation under STWs which represent 33.81 per cent of total cost.

Only a few farmers used insecticides in producing MV Boro paddy in the study area. Almost all the selected farmers, who used insecticides for their MV Boro paddy, were not sure about the name, brand, quantity and or/per unit price of the insecticides. Sometimes, they even did not know which insecticides should be used. In the most cases they used insecticides as per suggestions of insecticide traders, neighboring farmers, friends and relatives. This cost includes the actual costs incurred by farmers for purchasing insecticides from the dealers or retailers. It was found that per hectare cost of insecticide and herbicide for STWs farmers was Tk. 208 respectively, which was 0.55 per cent of total costs. Major farmers in the study areas did not use any insecticide and herbicide in their plots and for this reason the cost of insecticide and herbicide was very low.

The price of land was different for different plots depending upon location and topography of the soil. Land use cost considered the land renting arrangement prevailed in the study areas. In the study area, for renting one Pakhi (33 decimals) of land in Boro season, farmers (tenant) had to pay $240 \mathrm{~kg}$ of paddy to the land owner. On the basis of this value of paddy for renting one hectare of land was estimated as Tk. 11,520 which considered as land use cost. Interest on operating capital (OC) included all costs in the process of growing MV Boro paddy excluding which interest had already been charged. Interest on $\mathrm{OC}$ was estimated considering 10 per cent bank interest rate. The rate was also used recently by several researchers (Sarwer, et. al., 2008; Nargis, 2008). The Interest on OC on an average was Tk. 920 for MV Boro paddy production under, which cover 2.44 per cent of total costs.

Per hectare costs for producing MV Boro paddy under STWs was Tk. 37,716. Per hectare yield of Boro rice was $5100 \mathrm{~kg}$ and average price of Boro rice at harvesting period was Tk. 10 per kg (Table 3). Per hectare gross margin of MV Boro paddy was Tk. 16,350 and net returns was Tk. 15,430 per hectare. 
Table 3. Per hectare yield, cost and return of MV Boro paddy production under STW irrigation

\begin{tabular}{l|c}
\hline \multicolumn{1}{c|}{ Particulars } & Yield, cost and return \\
\hline Yield (main product/paddy) (kg/ha) & 5100 \\
Unit price (Tk/kg) & 10.00 \\
Value of main product (Tk/ha) & 51,000 \\
Value of by product/Straw (Tk/ha) & 2,146 \\
Gross returns (Tk/ha) & 53,146 \\
Total variable cost (Tk/ha) & 36,796 \\
Gross margin (Tk/ha) & 16,350 \\
Total cost (Tk/ha) & 37,716 \\
Net return (Tk/ha) & 15,430 \\
\hline
\end{tabular}

Source : Nargis (2008)

Two types of MV Boro producers such as (i) single water buyers and (ii) the water buyers who sold water also were found in the study areas. The farmers who bought water only earned comparatively higher profit from Boro production may be due to intensive care for involvement in single job, though a huge variation in profit earnings among water buyers (standard deviation was 18526 is higher than average profit) were existed (Table 4). So, specialized farming was also a factor to earning higher profit.

Table 4. Dependability of profit of MV Boro paddy by types of farmers

\begin{tabular}{lcccc}
\hline \multicolumn{1}{c|}{ Types of farmers } & No. of buyers & Profit (Tk/ha) & Standard deviation of profit \\
\hline Single water buyer & 51 & 16070 & 18526 \\
Buyer and seller & 9 & 11801 & 6852 \\
\hline Total & 60 & 15430 & 17308 \\
\hline
\end{tabular}

Source Nargis (2008)

The variation of profit from MV Boro paddy with level of education of the farmers can be seen in Table 5. It was found that educated farmers earned higher profit. So, education is the important tool to earn higher profit in Boro production. Exception was found only for illiterate farmers, though these farmers earned the highest profit but it was not statistically rationale due to higher profit deviation between these farmers (standard deviation was much higher than average).

The age could be replaced by experiences of farmers in crop farming. Higher experienced farmers earned higher profit from Boro paddy. It can be said, experience in farming is another important tool to gain higher profit in Boro paddy production. But it is mater of concerns for inverse relationship between farmer experiences and higher profit deviation among famers (Table 6). The cause of this is unknown and further in-depth study is needed to investigate the real farming situation. 
Table 5. Profit of MV Boro paddy by education of level of farmers

\begin{tabular}{lcccc}
\hline \multicolumn{1}{c|}{ Level of education } & No. of buyers & Profit (Tk/ha) & Standard deviation of profit \\
\hline Illiterate & 23 & 18617 & 24390 \\
Primary & 23 & 11684 & 11468 \\
Secondary & 5 & 14985 & 10130 \\
SSC and above & 9 & 17104 & 9369 \\
\hline Total & 60 & 15430 & 17308 \\
\hline
\end{tabular}

Source : Nargis (2008)

Table 6. Profit of MV Boro paddy by age of farmers

\begin{tabular}{lcccc}
\hline \multicolumn{1}{c|}{ Age groups } & No. of buyers & Profit $(\mathrm{Tk} / \mathrm{ha})$ & Standard deviation of profit \\
\hline $30-40$ years & 16 & 11058 & 10698 \\
$41-50$ years & 22 & 14490 & 11302 \\
51-60 years & 16 & 19254 & 27780 \\
Above 60 years & 6 & 20335 & 14118 \\
\hline Total & 60 & 15430 & 17308 \\
\hline
\end{tabular}

Source : Nargis (2008)

Table 7. Annual household income of water buyers

\begin{tabular}{lccc}
\hline \multicolumn{1}{c|}{ Income sources } & Annual income (Tk) & Percentage of total \\
\hline Aman rice & 1,153 & 1.38 \\
Boro rice & 24,561 & 29.34 \\
Mustard, pulses, jute, wheat, sugarcane and vegetables & 5,609 & 6.70 \\
Water selling & 4,702 & 5.62 \\
Livestock, poultry and fisheries & 4,142 & 4.95 \\
Services & 2,891 & 3.45 \\
Business & 7,008 & 8.37 \\
Remittance & 25,583 & 30.56 \\
Labor selling and rickshaw pulling & 6,422 & 7.67 \\
Others (trees selling) & 1,635 & 1.95 \\
\hline Average & 83,706 & 100 \\
\hline
\end{tabular}

Source : Nargis (2008)

\section{Household income of water buyers}

Remittance was the major source of household income for water buyers about similar to water seller but they earned the second highest income from Boro rice (29.34 per cent). Table 7, obviously, reveals that household income of water buyers prominently depend on Boro rice in rural areas. Small but countable amount of income came from business, 
services and labour selling and rickshaw pulling. Aman rice is also their main source of household income but the crop is not risk free and the income from this crop is sometimes uncertain. Due to flood and heavy rainfall they lost their Aman rice and got 1.38 Per cent of total household income which was very insignificant. Average household income of water buyers was much lower than water sellers because the landless, tenant, marginal farmers also engaged with water buying.

\section{CONCLUSION}

Among the costs items for producing MV Boro paddy, human labour was the vital one. Cost of irrigation was the second highest which is essential for MV Boro paddy production. The yield of MV Boro paddy was quite satisfactory in the study areas. Farmers earned a significant profit from MV Boro paddy. Specialized, experienced and educated farmers earned comparatively higher profit than those of other diversified, less experienced and lower educated farmers. Specialized farming, knowledge sharing and education of the farmers could be the ways of increased farm profit. In such way, the farmers earn a handsome amount which contributed around 29 per cent of total household income. Boro rice contributed 55 per cent of total rice production in 2004/05. So, increase of Boro rice production would be a significant possible way to remove food deficiency in the country. Irrigation is the vital input for crop cultivation in Rabi season in Bangladesh. So, developments of irrigation facilities are the crucial issue to increase and sustain MV Boro production. Only one fourth of the young farmers were engaged in Boro production, so impressive extension works could involve more number of youths which would create a seasonal employment in the country.

\section{REFERENCES}

Ali, M. W. 2001. An investigation into the yield gap of MV Boro paddy between the research station and farmers field: a case of Bogra district. M. S. Ag. Econ. Thesis, Bangladesh Agricultural University, Mymensingh.

BBS, 2006. Statistical Yearbook of Bangladesh, Bangladesh Bureau of Statistics, Statistics Division, Ministry of Planning, Government of the People's Republic of Bangladesh, Dhaka.

Nargis, F. 2008. Impact of Increased Energy Prices on Income of STW Owners and Water Buyers in Some Selected Areas of Ghatail Upazila in Tangail District., M. Sc. Ag. Econ. Thesis, Bangladesh Agricultural University, Mymensingh.

Rahman, R. 2000. Economics of BR-29 Boro paddy production of Melandah Uazila of Jamalpur district. M. S. Ag. Econ. Thesis, Bangladesh Agricultural University, Mymensingh.

Sarwer, R. H., Rahman, W., Ahmed, R., Alauddin, M. and Sharmin, A. 2008. Shallow Tubewell Irringation Business in Bangladesh. A field study in Dighalkandi Union under Ghatail Upazila of Tangail District, 2008, A research report submitted to IWMA, India.

Yang, W. Y. 1962. Methods of Farm Management Investigations for Improving Farm Productivity, Food and Agricultural Organization of the United Nations, Rome. 